\title{
The Gordon Growth Model: A Teaching Case
}

Jerome Duncan, Ph.D., Tuskegee University, USA

Seth C. Anderson, Ph.D., C.F.A., Tuskegee University, USA

Sherrell Price, Ph.D., Tuskegee University, USA

Cassandra Thomas, Ed.D., Tuskegee University, USA

\begin{abstract}
This case illustrates how the Gordon Growth Model is employed to estimate the value of a firm's stock. The model determines the value of stock based on dividends, growth rate, and the cost of capital. The Capital Asset Pricing Model (CAPM) is employed to calculate the cost of capital. Both economic analysis and ratio analysis are used to examine the impact of external and internal factors on share worth. The case discusses why the market share price may vary from an estimation of its worth. This case study can be used in an Introduction to Investments course, an Advanced Investments course, or a first level MBA graduate course.
\end{abstract}

Keywords: Economic Education; Gordon Growth Model; Teaching Example; Stock’s Worth

\section{INTRODUCTION}

tanding in front of the investments class, Professor Benjamin Jones starts, "Well, we are about to finish this semester. We will bring together the highlights of what we've learned on valuing common stock. We will initially look at the importance of different macroeconomic factors on the company. Next, we'll consider basic financial ratios in an analysis of how a firm's financing and operations impact its worth." $\mathrm{He}$ distributes copies of Figure 1.

\footnotetext{
${ }^{1}$ An earlier version of this paper ("A Pedagogical Presentation of the Gordon Growth Model") appeared in American Institute of Higher Education: Fifth International Conference Proceedings, Volume 3, Number 2, September 29-October 1, 2010, pp. 79-82.
} 
Figure 1. The Gordon Growth Model

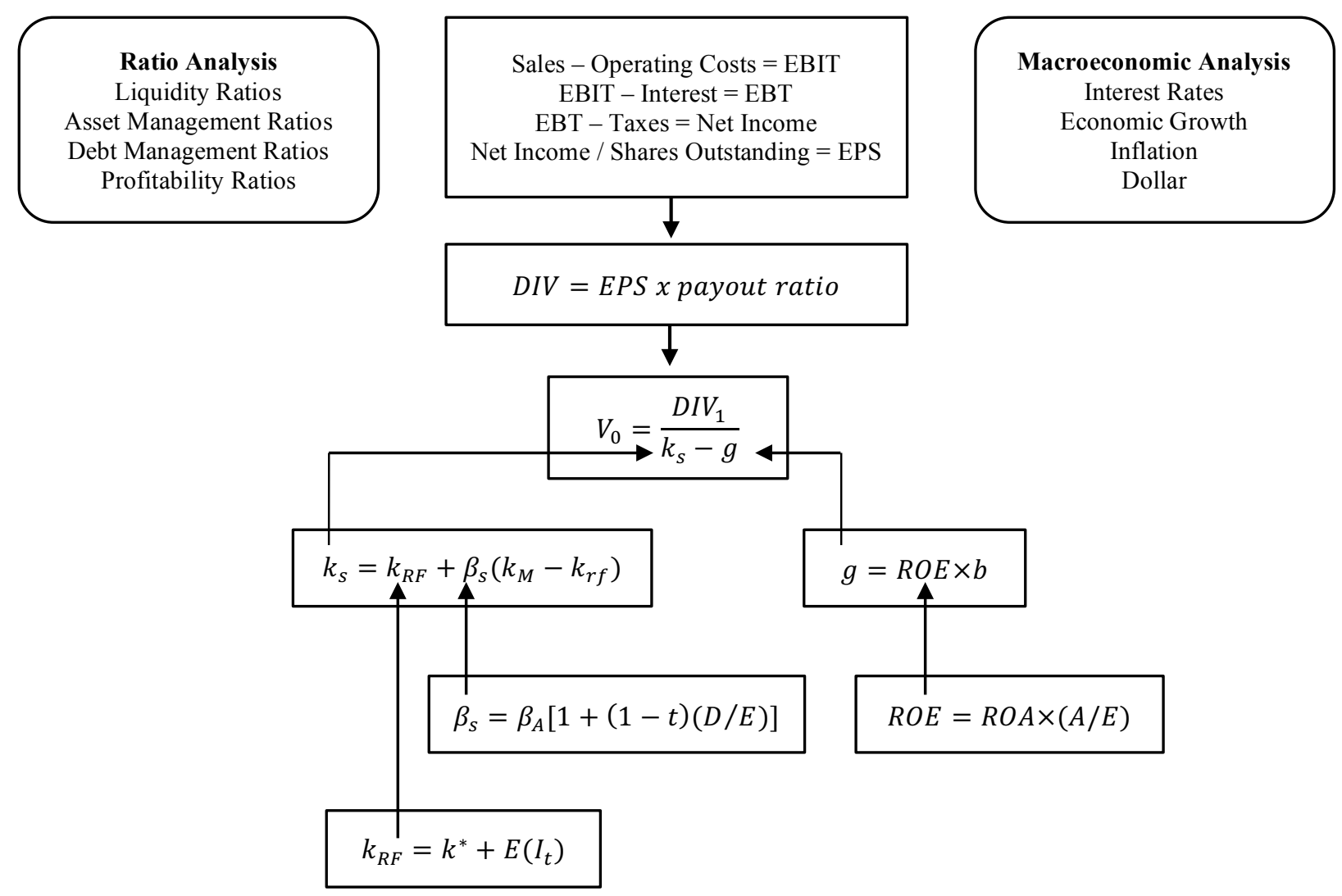

"Take a minute to study this and we'll review it in-depth. I'll call on you to discuss different components of the diagram. Who knows what the 'heart' of the valuation model is termed?"

\section{THE GORDON GROWTH MODEL}

Student A: "Its name is the Gordon Growth Model, and it is there in the middle of the handout."2

$$
V_{0}=\frac{D I V_{1}}{k_{s}-g}
$$

Professor Jones: "What do the different letters represent?"

Student B: " $V_{0}$ is the stock price at period $0 . "$

Professor Jones: "Hold it. We need to remember that this model estimates what the price of a stock ought to be. We all know what a stock's price is. As an example, the market price of Ford is $\$ 15$ per share. However, the Gordon model estimates a stock's value at period 0 , which is the present. Continue with your explanation."

Student B: "DIV $V_{l}$ is the expected dividend at period 1, which is next period's dividend. $k_{s}$ represents the stock's required rate of return, and $g$ is a level growth rate."

\footnotetext{
${ }^{2}$ The model is discussed in primary finance and investment texts, such as those by Keown, A. J., et al. and Ross, S., et al. It was originally introduced by Gordon, M.J. \& Shapiro, E. in a 1956 Management Science article. See the references.
} 
Professor Jones: "Can anyone tell me about dividends?"

Student $C$ : "Dividends refer to money paid to shareholders out of a company's earnings. Dividends are usually equal to a percentage of earnings per share. This is illustrated in Figure 1, right above the Gordon Model."

Professor Jones: "That's right. How are earnings per share computed?"

Student D: "The company's net income is divided by the number of outstanding shares."

Professor Jones: "That's correct. The model assumes that the dividend is a constant payout percentage of earnings per share. It also assumes a level earnings growth rate $g$ which results in a growing dividend over the future."

$$
\begin{aligned}
& D I V_{t}=D I V_{0}(1+g)(1+g)^{t} \\
& t=1, \ldots, \infty
\end{aligned}
$$

"Remember that the subscript $t$ represents each period. So, $D I V_{0}$ is the current dividend, and $D I V_{l}$ is next period's dividend. Who knows why the infinity sign ends the time series?"

Student A: "That's because we expect the dividend to grow forever."

Professor Jones: “Correct. Now we'll look more closely at $k_{s}$ and $g$. Who can help with this?"

Student E: " $k_{s}$ is the required rate of return on the common stock of the company."

Professor Jones: "Good. We'll talk more about $k_{s}$ when we get to it shortly. Now, what about $g$ ?"

Student A: "It stands for the company's growth rate. It is shown below the Gordon Growth Model."

$$
g=R O E \times b
$$

Professor Jones: "Who can explain the growth rate formula?"

Student B: "The determinants of growth $g$ are $R O E$, which stands for return on equity, and $b$, which stands for the profit retention ratio and equals ( 1 - payout ratio). The firm's growth is a function of the amount of money it keeps for reinvestment and the return it generates on these investments."

Professor Jones: "That's correct, and you'll recall that $R O E$ is computed by multiplying the asset-to-equity ratio times the return generated on assets, as is seen on the lower right of Figure 1. Now let's look more closely at $k_{s}$. This is the required rate of return on the common stock of the company."

\section{THE CAPM}

Professor Jones: "How do we compute the required rate $k_{s}$ ? You learned about this in your basic finance class."

Student E: "The formula for this is seen on the lower left side of Figure 1. It is shown as:

$$
k_{S}=k_{R F}+\beta_{S}\left(k_{M}-k_{R F}\right) . "
$$

Professor Jones: “That's correct. As you'll remember, this model is called the Capital Asset Pricing Model, or the CAPM for short. This is how $k_{s}$ is computed. Now, define the parts of the model."

Student $A$ : " $k_{R F}$ equals the risk-free rate, which is usually the treasury bill rate. $k_{M}$ is the market's rate of return. $\beta_{s}$ 
represents the stock's beta, which is the stock's sensitivity to changes in the overall stock market."

Professor Jones: "Let's look more closely at a stock's beta. Who can write the equation on the board?"

Student B: "Here it is:"

$$
\beta_{S}=\beta_{A}\left(1+\frac{D}{E}\right)(1-t)
$$

"The terms in this equation are: $\beta_{A}$ which equals the beta associated with the firm's business risk, $D / E$ which represents the debt/equity ratio, and $T$ which is the tax rate."

Professor Jones: "Good job. The stock's beta, $\beta_{s}$, reflects both the business risk and the financial risk of the firm. The equation demonstrates three concepts: (1) the separation of business and financial risk, (2) the tax subsidy for using debt, and (3) the effect of leverage on the stock's risk. We'll come back to these later. For now, who is willing to explain $k_{R F}$, which is the risk-free rate."

Student B: "We learned in basic finance that the risk-free rate, $k_{R F}$, is computed by adding the real rate of interest, $k^{*}$, to the expected inflation rate, $E\left(I_{t}\right)$. The treasury bill rate is used for the risk-free rate $\left(k_{R F}\right)$. We see this relationship in Figure 1."

$$
k_{R F}=k^{*}+E\left(I_{t}\right)
$$

Professor Jones: "Now it's time to look at changes in the components of the Gordon Model."

\section{THE IMPACT OF CHANGES IN $D I V_{l}, k_{s}$, and $g$}

Professor Jones: "We'll look at how the right-hand-side components of the Gordon Growth Model can impact $V_{0}$, or the estimated value of a stock. To do this, we assume that only one component changes at any one time. You will remember from your economics that the term for holding everything constant except for one variable is ceteris paribus. What happens when the dividend increases?"

Student A: "The estimated worth of the stock will rise."

Professor Jones: "And what about an increase in $k_{s}$ ?"

Student B: "If $k_{s}$ rises, then the denominator increases in size and $V_{0}$ declines."

Professor Jones: "And what about an increase in the growth rate?"

Student B: "Then the denominator decreases and the estimated value of the stock rises."

Professor Jones: “That's good. Now, let's see how various macroeconomic factors affect the firm and its stock's worth."

\section{MACROECONOMIC FACTORS: THE FIRM AND ITS SHARE VALUATION}

Professor Jones: "Before we get started, we must not forget that we will consider the impact of each macroeconomic variable on the firm and its estimated share price, certeris paribus. For example, we'll consider the impact of economic growth on the firm and on its share value. Who knows how the growth rate of the overall economy impacts a typical firm?"

Student A: "If the economy grows, then most firms' sales or revenues will increase."

Professor Jones: "What effect does the growth in revenues then have?" 
Student B: "Looking at the top box in Figure 1, we see that increased sales will increase earnings per share (EPS) and dividends will go up."

Professor Jones: "Right. Now, what if interest rates rise? What will happen to the firm? We'll assume that the company uses ongoing debt financing in its operations. However, not all firms employ debt."

Student D: "A rise in interest rates will increase expenses and will drive down EPS."

Professor Jones: "Good, and what about an increase in inflation?"

Student C: "An increase in inflation will likely drive up the company's operating costs, and profits will drop."

Professor Jones: "OK, let's look at the impact of a rise in the dollar in the currency market. What will be the effect of this?"

Student D: "If the company has foreign operations, then the foreign currencies they earn will be worth less if the dollar rises. Thus, their EPS will probably decline."

Professor Jones: "However, if they don't have foreign operations but import goods for sale or use, then their profits increase because the foreign goods cost less due to the strong dollar. Now, let's look at these same macro variables and the Gordon Model. How might economic growth impact the right-hand-side component?"

Student B: "The growth rate $g$ rises."

Professor Jones: "We know that if $g$ goes up, then the denominator declines and $V_{0}$ rises. What about a rise in interest rates?"

Student $A$ : "Then $k_{s}$ will go up, and the denominator rises, causing $V_{0}$ to fall."

Professor Jones: "Does it matter whether interest rates rise because of an increase in the real rate or because inflation goes up?"

Student B: "It should not matter, ceteris paribus."

Professor Jones: "What would be the effect of a change in the dollar's value?"

Student A: "It seems that a change in the exchange rate impacts $V_{0}$ only through its impact on the operations of the firm, which ultimately affects dividends."

Professor Jones: “Now, let's move on and look at the firm's operating and financial ratios to see how changes in the factors involved might ultimately impact the Gordon Model."

\section{RATIO ANALYSIS: THE FIRM AND ITS SHARE VALUATION}

Professor Jones: "Here, we'll look at the basic financial ratios to see how share price can be affected by changes in various firm factors. We will consider each ratio briefly. We must remember that ratios can be used when comparing different firms or they can be used for the same firm over time. The ratios we will employ are listed in Table 1, and we will consider changes over time. Who can tell me one way that changes in the current ratio variables affect $V_{0}$ ?" 
Table 1. Ratios

\begin{tabular}{l|l}
\hline \multicolumn{1}{c|}{ Ratio } & \multicolumn{1}{c}{ Formula } \\
\hline Liquidity & \\
\hline Current & (Current Assets)/(Current Liabilities) \\
\hline Quick & (Current Assets - Inventories)/(Current Liabilities) \\
\hline $\begin{array}{l}\text { Asset Management } \\
\text { Inventory Turnover }\end{array}$ & (Sales)/(Inventories) \\
\hline Days Sales Outstanding (DSO) & (Receivables)/(Annual Sales/365) \\
\hline $\begin{array}{l}\text { Fixed Assets Turnover } \\
\text { Debt Management } \\
\text { Total Debt to Total Assets }\end{array}$ & (Sales)/(Net Fixed Assets) \\
\hline $\begin{array}{l}\text { Times-Interest Earned (TIE) } \\
\text { Profitability }\end{array}$ & (Total Debt)/(Total Assets) \\
\hline Profit Margin on Sales & (Earnings Before Interest and Taxes (EBIT))/(Interest Charges) \\
\hline Return on Total Assets (ROA) & \\
\hline Return on Common Equity (ROE) & (Net Income)/(Sales) \\
\hline
\end{tabular}

Student A: "If the ratio of current assets to current liabilities falls too low, then the firm may have to increase shortterm financing or sell inventory at distressed prices to pay its current liabilities. These actions could hurt EPS and put downward pressure on the stock price."

Professor Jones: "Good. What about the quick ratio that subtracts inventories from current assets?"

Student B: "This shows the proportion of liquid current assets relative to current liabilities. Again, if this ratio falls, then the cost of meeting short-term liabilities will probably rise and ultimately push $V_{0}$ down."

Professor Jones: "Now, let's take a look at inventory turnover, which is an asset management ratio. If sales rise relative to inventories, what might this indicate?"

Student C: "Assuming the company is profitable, then this would likely increase earnings per share and push share value up."

Professor Jones: "Good. And what about the day sales oustanding (DSO) ratio?"

Student $D$ : "If receivables rise relative to daily sales, then the expenses created by receivables will increase, thereby hurting EPS; so $V_{0}$ will decline."

Professor Jones: “In a similar vein, what about fixed assets' turnover?"

Student E: "A rise in sales relative to net fixed assets may increase total profits, increasing $E P S$; so $V_{0}$ should rise." Professor Jones: "Now, let's look at two debt management ratios. What might be the effect of a rise in the total debt to total asset ratio?"

Student A: "First, it could push interest exposure up and EPS down, causing a fall in $V_{0}$. Simultaneously, it would increase the $D / E$ component for the firm's $\beta_{s}$, thus driving up $k_{s} . "$

Professor Jones: "Now, let's consider the times-interest-earned ratio."

Student C: "An upward change in this ratio shows that the firm is generating more earnings which can be used to pay interest charges. This could ultimately push down borrowing costs, which would be positive for EPS and $V_{0}$."

Professor Jones: "Now, let's look at profitability ratios. Who will address profit margin on sales?"

Student D: "If net income on sales is rising, then the firm's profitability is improving. EPS should rise, which should increase $V_{0} . "$ 
Student E: "The same holds for the return on assets ratio and the return on common equity ratio."

Professor Jones: “That's correct. As EPS rises, DIV ${ }_{l}$ rises and $V_{0}$ has to rise also, ceteris paribus.

\section{IMPORTANT ISSUES}

Professor Jones: "Now that we have seen how changes in various firm factors might impact $V_{0}$, we must be careful to remember that reported ratios represent historical data."

Student A: "What is the problem with that?"

Professor Jones: "The Gordon Model is a forward-looking model. Each of the right-hand side variables represents future metrics. Dividends are for next year, and both $k_{s}$ and $g$ are assumed constant into the future."

Student B: "I guess this means that our forecasts of the future must be accurate if we think our estimate of $V_{0}$ is worth much."

Professor Jones: "That's correct. This is the nature of the model. However, we must have some context out of which to estimate the worth of a stock. This model at least gives us a consistent method for viewing the interrelationship of variables that drive a stock's prices."

Student $C$ : "Well then, how does this model explain why stocks can rise dramatically, then crater in price like they did during the tech bubble of the late 1990s and during 2009?"

Professor Jones: “That's a good question. The quote below gives some information from a Wall Street Journal (January 2010) article by Jason Zweig on page B1, which deals with market efficiency. As you remember, if markets are efficient, they reflect all of the information available about a security. Let's take a look at the following excerpt, which is quoted directly from that article."

"In 1974, the great financial analyst Benjamin Graham wryly described the efficient-market hypothesis as a theory that 'could have great practical importance if it coincided with reality.' Mr. Graham marveled at how Avon Products, which traded at $\$ 140$ a share in 1973, had sunk below \$20 in 1974: 'I deny emphatically that because the market has all the information it needs to establish a correct price the prices it actually registers are in fact correct.'

Mr. Graham proposed that the price of every stock consists of two elements. One, 'investment value,' measures the worth of all the cash a company will generate now and in the future. The other, the 'speculative element,' is driven by sentiment and emotion: hope and greed and thrill-seeking in bull markets, fear and regret and revulsion in bear markets.

The market is quite efficient at processing the information that determines investment value. But predicting the changing emotions of tens of millions of people is no easy task. So the speculative element in pricing is prone to huge and rapid swings that can swamp investment value."3

Student D: "So, even if we correctly estimate the Gordon Model, the actual price of stock may differ widely from our estimate?"

Professor Jones: "That's correct. If its market price is above your estimate, then the stock should probably be sold, and vice versa."

${ }^{3}$ Zweig, J. (2010, January 9-10). Inefficient Markets Are Still Hard to Beat, The Wall Street Journal, p. B1. 


\section{CONCLUSION}

This case exhibits how the Gordon Growth Model is employed as a framework for estimating the value of a firm's stock. The model employs dividends, the cost of a firm's equity, and the firm's growth rate to arrive at an estimate of stock price. The Capital Asset Pricing Model (CAPM) is used to compute the cost of capital. Both economic analysis and ratio analysis are utilized to show the impact of external and internal factors on share worth. The case ends with a discussion of why actual share price may vary significantly from an estimation of its worth.

\section{QUESTIONS}

When answering the following questions asked by Professor Jones, please assume these metrics:

$k_{s}=10 \% \quad g=5 \% \quad D I V_{I}=\$ 1 \quad k_{R F}=3 \% \quad \beta_{s}=1$

1. What is the estimated worth of ABC's stock?

2. Assume ABC's growth rate rises to 6\%. How does this affect ABC's stock?

3. If $\mathrm{ABC}$ is not expected to grow, what will its stock price become?

4. If $k_{s}$ for $\mathrm{ABC}$ rises to $12 \%$, what will its stock price become?

5. If $\mathrm{ABC}$ increases its debt level, what effect will it have on its $\beta_{s}$ ?

6. How might an increase in inflation impact $\mathrm{ABC}$ 's $k_{s}$ ?

7. If Congress raises corporate taxes from current levels, how will this impact the firm's profits?

8. If Congress raises corporate taxes from current levels, how will this impact the firm's beta?

9. If domestic inflation rises, what impact would it have on the firm's exports, and how will this affect its price?

10. Explain why $k_{s}$ must be less than $g$.

11. What are the advantages of using the Gordon Growth Model, which is premised on expected future dividends?

12. If $A B C$ increases its debt level but does not increase its profits (the bottom line), what is the initial effect on its stock price?

13. The model shows that a company's stock price is sensitive to the dividend growth rate chosen, and that the growth rate cannot exceed the cost of equity. Is this always true?

14. What is the difference between the two versions of the Gordon Growth Model — the stable growth model and the multistage growth model? 


\section{ANSWERS TO QUESTIONS}

1. $(\$ 1) /(.10-.05)=\$ 20$

2. It will rise by $\$ 5$. $(\$ 1) /(.10-.06)=\$ 25$

3. It will fall to $\$ 10$. $(\$ 1) /(.10-.05)=\$ 10$

4. It will fall to $\$ 14.29$. $(\$ 1) /(.10-.05)=\$ 14.29$

5. It will cause $\beta_{s}$ to rise.

6. It will cause $k_{s}$ to rise.

7. It will cause profits to decline.

8. It will cause $\beta_{s}$ to decline.

9. A rise in inflation will likely cause both exports and profits to fall. The decline in profits will ultimately cause $g$ to decline.

10. If $k_{s}$ is less than $g$, then the price will go negative, which is not possible.

11. The advantages are twofold: (1) it is easy to use, and (2) it allows one to compare companies of different sizes and across different industries.

12. A firm can increase the debt ratio by issuing new debt, or it can decrease the ratio by divesting assets and using the proceeds to reduce debt. In the first case, the debt level increases and the expectation is that the stock price will decrease because higher debt equates to higher risk, ceteris paribus.

13. It is not a matter of true or false. It is simply that the model is not suited to value a growth rate in excess of the cost of equity.

14. The multi-stage growth model assumes that dividend growth "eventually becomes constant," and the stable model assumes that dividends grow at a constant rate forever. This latter assumption is not always realistic.

\section{AUTHOR BIOGRAPHIES}

Dr. Jerome Duncan received the Ph.D. degree in finance in 1980 from University of Florida. Over the years he served on the faculty at University of Manitoba, Hofstra University, University of Memphis, and Tuskegee University. Dr. Duncan retired from Tuskegee University in May 2014.

Dr. Seth C. Anderson received his M.B.A. degree in 1980 from Auburn University. In 1984 he received the Ph.D. degree in finance from University of North Carolina. Over the years he served on the faculty at Wake Forest University, University of Alabama at Birmingham, Auburn University, Huntingdon College, University of North Florida, and Tuskegee University. Dr. Anderson retired from Tuskegee University in May 2013

Dr. Sherrell Price received her M.B.A. degree in 1985 from Alabama A \& M University. In 1994 she received the Ed.D. in Higher Education Administration from the University of Alabama, with a concentration in Human Resource Management. In 2012 she completed the Postdoctoral Bridge Program in Finance and Accounting at the College of Business Administration at University of Florida. Dr. Price has served on the faculty at Alabama A\&M University, Miles College, and Tuskegee University. Currently she holds the rank of Assistant Professor at Tuskegee University.

Dr. Cassandra Thomas received her M.S. degree in computer science in 1987 from DePaul University. In 2013 she received an Ed.D. degree from Alabama State University. Dr. Thomas has served on the faculty at Tuskegee University since 2001 and holds the rank of Assistant Professor.

\section{REFERENCES}

Duncan, J., \& Anderson, S. (2010, September 29-October 1). A Pedagogical Presentation of the Gordon Growth Model. Paper presented at the American Institute of Higher Education: Fifth International Conference, Orlando, FL.

Gordon, M.J., \& Shapiro, E. (1956). Capital Equipment Analysis: The Required Rate of Profit. Management Science, 3(1), 102110.

Keown, A., Martin, J., \& Petty, J. (2010). Foundations of Finance ( $7^{\text {th }}$ ed.). Boston, MA: Prentiss-Hall.

Ross, S., Westerfield, R., \& Jordan, B. (2010). Essentials of Corporate Finance ( $7^{\text {th }}$ ed.). New York, NY: McGraw-Hill, Irwin. Zweig, J. (2010, January 9-10). Inefficient Markets are Still Hard to Beat, Wall Street Journal, p. B1. 
